\title{
Real-time Mud Gas Monitoring: A Technique to Obtain Information on the Composition and Distribution of Gases at Depth While Drilling
}

by Thomas Wiersberg and Jörg Erzinger

doi:10.2204/iodp.sd.s01.36.2007

Several techniques have been applied to obtain information on the composition of gases and fluids in drill holes, such as downhole fluid sampling, gas and fluid analysis during pumping tests, or in vacuo degassing of drill core samples. All these techniques can yield valuable information on the geochemistry of gases, but they are less useful for obtaining a continuous dataset on the distribution and composition of gases at depth. To reveal such data during drilling, we have developed a technique where gas is extracted from circulating drill mud with an agitator and continuously piped into a nearby laboratory trailer for on-line analysis. In addition, we routinely determine electrical conductivity, $\mathrm{pH}$, and temperature continuously during the drilling operation within the mud pit at 10 -min intervals.

Hydrocarbons, helium, radon, and carbon dioxide are the most suitable gases for the real-time detection of fluidbearing horizons such as shear zone, open fractures, sections of enhanced permeability, and occurrences of permafrost methane hydrate. Gas analysis is carried out with a quadrupole mass spectrometer for $\mathrm{N}_{2}, \mathrm{O}_{2}$, $\mathrm{Ar}, \mathrm{CO}_{2}, \mathrm{CH}_{4}, \mathrm{He}, \mathrm{H}_{2}$, and $\mathrm{H}_{2} \mathrm{~S}$; a gas chromatograph (GC) equipped with a flame ionization detector (FID) for hydrocarbons $\left(\mathrm{CH}_{4}, \mathrm{C}_{2} \mathrm{H}_{6}, \mathrm{C}_{3} \mathrm{H}_{8}, \mathrm{n}-\mathrm{C}_{4} \mathrm{H}_{10}\right.$, and i- $\mathrm{C}_{4} \mathrm{H}_{10}$ ), and a custom-built Lucas cell alpha-detector for ${ }^{222} \mathrm{Rn}$ activity. When significant amounts of non-atmospheric gases are detected, off-line gas samples are automatically collected from the gas line for further investigations on isotopes (e.g. noble gases, carbon, and hydrogen) to reveal information on the origin and evolution of deep-seated fluids. The technique has been applied successfully on several International Continental Scientific Drilling Program (ICDP) projects, such as SAFOD (San Andreas Fault
Observatory at Depth), Mallik, and German Continental Deep Drilling Program KTB (Erzinger etal., 2004; Wiersberg et al., 2005; Zimmer and Erzinger, 1995).

As an example, we present results from the SAFOD Main Hole, drilled in 2004-2005 within the framework of ICDP. SAFOD wants to achieve a better understanding on the processes at active plate-bounding fault systems at the location of their origin. Knowledge about the role and origin of fluids and gases associated with the San Andreas Fault (SAF) zone is relatively poor. Besides the open question on how fluids are linked with fault zone processes in general, outstanding topics include the spatial distribution of fluids at depth, and, in particular, the contribution of mantle-derived fluids to the total fluid inventory of the SAF.

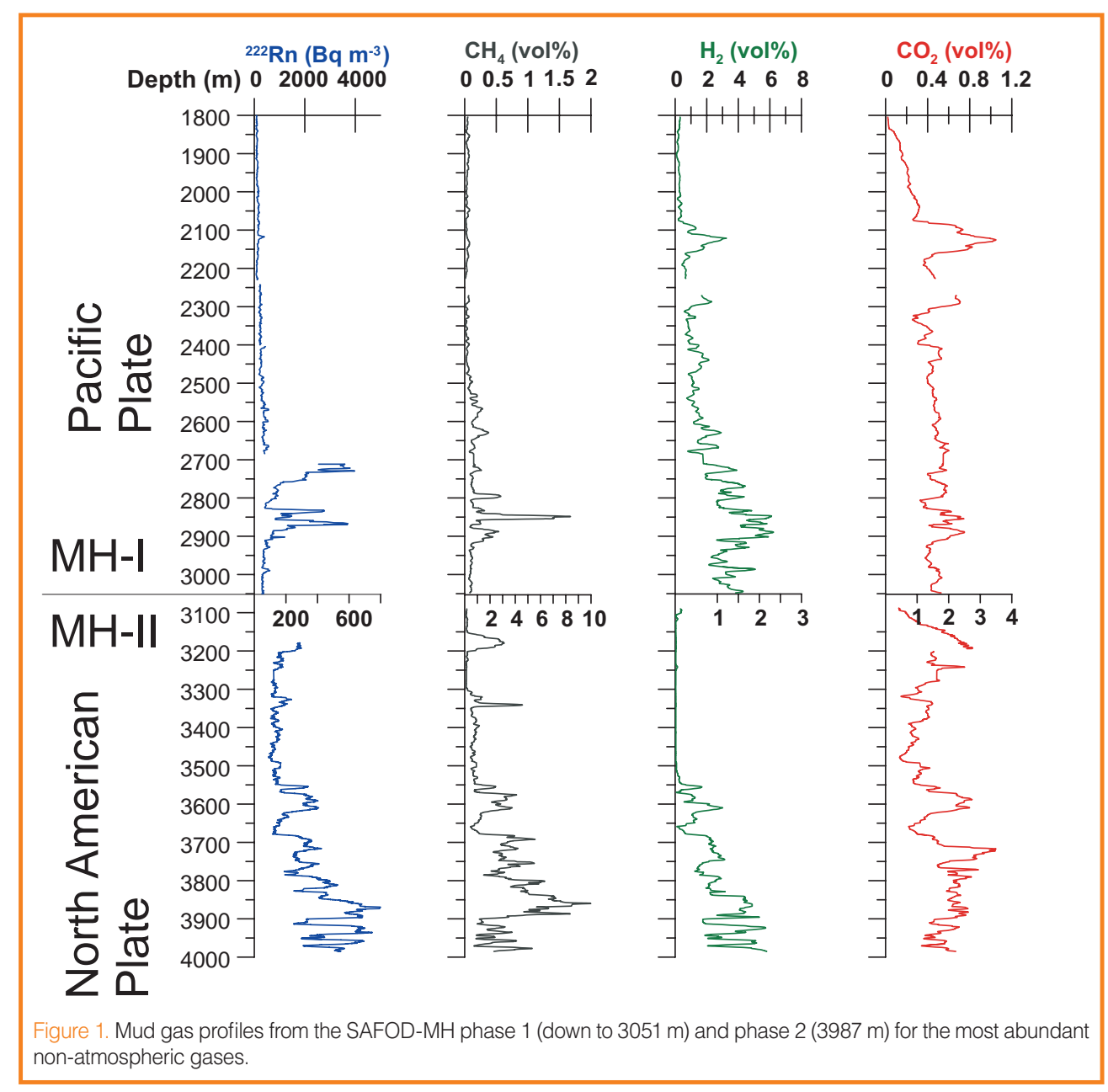


The pilot hole $(\mathrm{PH})$ and the main hole $(\mathrm{MH})$ were both drilled at a short distance from each other. In contrast to the vertical PH, which penetrates $768 \mathrm{~m}$ of Quarternary and Tertiary sediments into Cretaceous granite down to $2168 \mathrm{~m}$ final depth, the MH was deviated towards the SAF and reenters sedimentary strata below $1930 \mathrm{~m}$, where it remains down to the bottom of the hole $(3987 \mathrm{~m})$. Geophysical and geological observations identify the SAF in a depth interval of $\sim 3100-3450 \mathrm{~m}$.

In the lower, sedimentary part of the SAFOD-MH, drilled in $2004(1900-3051 \mathrm{~m})$ and $2005(3051-3980 \mathrm{~m})$, the most abundant non-atmospheric gases in drill mud were hydrogen (up to $6 \mathrm{vol} \%$ ), methane (up to $10 \mathrm{vol} \%$ ), and carbon dioxide (up to $4 \mathrm{vol} \%$ ). The concentration of helium remained low $(>20 \mathrm{ppmv})$, whereas radon activity reached values of up to $5000 \mathrm{~Bq} \mathrm{~m}^{-3}$. Two major sections could be identified where these gases were enriched in mud gas: from $2700-2900 \mathrm{~m}$ and from $>3550 \mathrm{~m}$ to the bottom of the hole at $3987 \mathrm{~m}$ (Fig.1). A positive correlation between the numbers of beddings and fractures in these sections, identified by geophysical logging, and the radon activity implies that fluids enter the hole through open fissures. Furthermore, the radon activity indicates that the fluids are actively circulating. In both sections, radon also correlates positively with $\mathrm{H}_{2}, \mathrm{CO}_{2}$, and (in part) $\mathrm{CH}_{4}$; however, the relative proportions of these gases are different in both sections. The upper and lower sections are enriched in ${ }^{222} \mathrm{Rn}$ and $\mathrm{H}_{2}$, and in $\mathrm{CO}_{2}$ and $\mathrm{CH}_{4}$, respectively.

Based on their distinct chemical compositions, we conclude that both sections represent individual hydrologic systems. Evidence for mixing is only slight. The gas concentrations found in the drill mud between $2900 \mathrm{~m}$ and $3550 \mathrm{~m}$ depths are low, especially for ${ }^{222} \mathrm{Rn}$. Only two sections, at $3150-3200 \mathrm{~m}$ and at $3340 \mathrm{~m}$, show some higher gas concentrations. The spike at $3340 \mathrm{~m}$, very close to the active part of SAF $(3310 \mathrm{~m})$, is almost exclusively composed of hydrocarbons. We assume that these are trapped in permeable sands embedded in less permeable strata, an interpretation supported by lithological data.

The air-corrected ${ }^{3} \mathrm{He} /{ }^{4} \mathrm{He}$ ratios of off-line mud gas samples are lower than the atmospheric ratio, but higher than the mean crustal values of $\leq 0.1 \mathrm{Ra}$; therefore, helium is a mixture of crustal helium with a small portion of mantlederived helium. Down to a depth of $3051 \mathrm{~m}$, air-corrected ${ }^{3} \mathrm{He} /{ }^{4} \mathrm{He}$ ratios of $>0.45 \mathrm{Ra}$ show that the contribution of mantle-derived helium is small (approx. 5\%) on the Pacific plate, which composes the southwestern portion of the SAF. The ${ }^{3} \mathrm{He} /{ }^{4} \mathrm{He}$ ratios become significantly higher at depths below $3500 \mathrm{~m}$ on the North American plate, where ${ }^{3} \mathrm{He} /{ }^{4} \mathrm{He}$ ratios of $0.9 \mathrm{R}_{\mathrm{a}}$ were found, revealing a mantle contribution of $10 \%-12 \%$ for the total helium budget (Wiersberg and Erzinger, 2007).
Based on our observations, we conclude that the role of mantle-derived fluids in seismic processes at the SAF is small. The distinct helium isotopic compositions down to $3051 \mathrm{~m}$ and below $3500 \mathrm{~m}$ depths, with only little evidence for mixing between both hydrologic systems, again demonstrate that the SAF in some way acts as a barrier for fluid migration. Mantle-derived fluids migrate predominately through permeable country rock and leak to some extent into the SAF.

\section{References}

Erzinger, J., Wiersberg, T., and Dahms, E., 2004. Real-time mud gas logging during drilling of the SAFOD pilot hole in Parkfield, CA. Geophys. Res. Lett., 31:L15S18, doi:10.1029/ 2003GL019395.

Wiersberg, T. and Erzinger, J., 2007. A helium isotope cross-section through the San Andreas Fault at seismogenic depth. Geochem. Geophys. Geosyst., 8:Q01002, doi:10.1029/ 2006GC001388.

Wiersberg, T., Erzinger, J., Zimmer, M., Schicks, J., and Dahms, E., 2005. Real-time gas analysis at the Mallik 2002 gas hydrate production research well. In Dallimore, S.R. and Collett, T.S. (Eds.), Scientific Results from Mallik 2002 Gas Hydrate Production Research Well Program, Mackenzie Delta, Northwest Territories, Canada. Geological Survey of Canada, Bulletin 585.

Zimmer, M., and Erzinger, J., 1995. On the geochemistry of gases in formation and drilling fluids-results from the KTB. Sci. Drill., 5:101-110.

\section{Authors}

Thomas Wiersberg and Jörg Erzinger, GeoForschungsZentrum Potsdam, Section 4.2, Telegrafenberg B323, 14473, Potsdam, Germany, e-mail: wiers@gfz-potsdam.de. 